Article

\title{
Reactions of Dihaloboranes with Electron-Rich 1,4-Bis(trimethylsilyl)-1,4-diaza-2,5-cyclohexadienes
}

\author{
$\mathrm{Li} \mathrm{Ma}^{\dagger}$, Xiaolin Zhang ${ }^{\dagger}$, Wenbo Ming ${ }^{\dagger}(\mathbb{D}$, Shengxin Su, Xiaoyong Chang and Qing Ye $* \mathbb{( \mathbb { D }}$ \\ Department of Chemistry, Southern University of Science and Technology, Shenzhen 518055, China; \\ 11849423@mail.sustech.edu.cn (L.M.); zhangx16003@163.com (X.Z.); wenbo.ming@hotmail.com (W.M.); \\ 11510019@mail.sustech.edu.cn (S.S.); changxy@sustech.edu.cn (X.C.) \\ * Correspondence: yeq3@sustech.edu.cn; Tel.: +86-0-755-88018354 \\ t These authors contributed equally to this work.
}

Academic Editor: Ashok Kakkar

Received: 31 May 2020; Accepted: 16 June 2020; Published: 22 June 2020

\begin{abstract}
The reactions of electron-rich organosilicon compounds 1,4-bis(trimethylsilyl)-1,4-diaza2,5-cyclohexadiene (1), 2,3,5,6-tetramethyl-1,4-bis(trimethylsilyl)-1,4-diaza-2,5-cyclohexadiene (2), and 1,1'-bis(trimethylsilyl)-1,1'-dihydro-4, $4^{\prime}$-bipyridine (12) with $B$-amino and $B$-aryl dihaloboranes afforded a series of novel $\mathrm{B}=\mathrm{N}$-bond-containing compounds 3-11 and 13. The $\mathrm{B}=\mathrm{N}$ rotational barriers of $7(>71.56 \mathrm{~kJ} / \mathrm{mol}), \mathbf{1 0}(58.79 \mathrm{~kJ} / \mathrm{mol})$, and $\mathbf{1 3}(58.65 \mathrm{~kJ} / \mathrm{mol})$ were determined by variable-temperature ${ }^{1} \mathrm{H}-\mathrm{NMR}$ spectroscopy, thus reflecting different degrees of $\mathrm{B}=\mathrm{N}$ double bond character in the corresponding compounds. In addition, ring external olefin isomers $\mathbf{1 1}$ were obtained by a reaction between 2 and $\mathrm{DurBBr}_{2}$. All obtained $\mathrm{B}=\mathrm{N}$-containing products were characterized by multinuclear NMR spectroscopy. Compounds 5, 9, 10a, 11, and 13a were also characterized by single-crystal X-ray diffraction analysis.
\end{abstract}

Keywords: 1,4-bis(trimethylsilyl)-1,4-diaza-2,5-cyclohexadienes; salt-free reduction; rotational barrier; $\mathrm{B}=\mathrm{N}$ bond

\section{Introduction}

Low-valent boron compounds are a class of highly reactive species that have been the focus of intense research because of their unique electronic properties $[1,2]$ as well as their diverse and fascinating reactivity patterns such as inert bond activation [3,4], cycloaddition reaction [5-7], and small molecule activation [8]. The progress in this research area is highlighted by the very recent results in terms of borylene-mediated $\mathrm{N}_{2}$ activation [9] and $\mathrm{N}_{2}$ coupling [10]. Nonetheless, the synthetic approach to low-valent boron species is severely limited [11-13]. Almost all of the reported synthetic strategies require a strong metallic reducing agent (e.g., $\mathrm{Li}, \mathrm{K}, \mathrm{Na}, \mathrm{KC}_{8}$ ) [3,4,14-23], harsh reaction conditions, and a strict moisture- and oxygen-free atmosphere. Therefore, the exploration of metal-free reductants to access low-valent boron species is highly desirable [24-26].

Mashima et al. reported a class of electron-rich organosilicon compounds 1, 2, and 12, which can serve as versatile reducing reagents for the group 4-6 metal chloride complexes. The corresponding low-valent metal species were prepared in a salt-free manner [27-33]. The reducing power mainly derives from the aromatization of the central 1,4-diaza-2,5-cyclohexadiene ring. Deeply inspired by the advantage of the salt-free reduction protocol and easy workup, we decided to examine the ability of the organosilicon compounds 1, 2, and $\mathbf{1 2}$ for the reduction of trivalent dihaloboranes. Based on the published results, the disubstituted compounds $\operatorname{ArXB}\left(\mathrm{N}_{2} \mathrm{C}_{4} \mathrm{R}_{4}\right) \mathrm{BXAr}$ are proposed as the reduction products. We hypothesized two possible bonding modes (i.e., $\mathbf{A}$ and $\mathbf{B}$ in Scheme 1) between the $\mathrm{C}_{4} \mathrm{~N}_{2}$ ring and the boron atoms. In the first manner, $\mathrm{B}-\mathrm{N}$ is bound by an electron-precise $\sigma$ bond $(\mathrm{A}$, Scheme 1) and an additional $\mathrm{N}-\mathrm{B}$ dative $\pi$ bond. In the second manner, two nitrogen atoms each 
provide a $\pi$-electron for $6 \pi$-aromatization, while the remaining two valence electrons form a lone pair on each $\mathrm{N}$ atom, donating to the empty $s p^{2}$-hybridized orbital of boron, thus leading to the divalent boron radical centers (B, Scheme 1$)$.



Scheme 1. Proposed products from the reactions of $\mathrm{ArBX}_{2}$ with 1 and 2, and two possible bonding modes $\mathbf{A}$ and $\mathbf{B}$ between the central $\mathrm{C}_{4} \mathrm{~N}_{2}$ ring and the boron centers.

\section{Results and Discussion}

First, we examined compound 1 for its ability to reduce $\mathrm{ArBX}_{2}$. The results are summarized in Scheme 2. Compound 1 [34] and $\mathrm{ArBX}_{2}$ ( $\mathrm{Ar}=$ 2,3,5,6-tetramethylphenyl (Dur), 2,4,6-trimethylphenyl (Mes) [35] were prepared according to the literature. The reaction of 1 with an equimolar amount of $\mathrm{DurBBr}_{2}$ and $\mathrm{MesBCl}_{2}$ at ambient temperature afforded the expected monosubstituted products 3 and 4, respectively. Adding the second equiv. of dihaloboranes to the reaction mixture led to the disubstituted products $\mathbf{5}$ and $\mathbf{6}$. In stark contrast, the reaction of $\mathbf{1}$ with an equimolar amount of the less sterically demanding $\mathrm{PhBCl}_{2}$ caused precipitation, which is insoluble in all ordinary solvents. This is most likely due to the polymerization of $\mathrm{PhClBC}_{4} \mathrm{~N}_{2} \mathrm{H}_{4} \mathrm{SiMe}_{3}$ by chlorosilane elimination. Hence, the stepwise synthetic protocol is unsuitable for the synthesis of $\mathbf{7}$. Instead, $\mathbf{1}$ was directly treated with 2 equiv. of $\mathrm{PhBCl}_{2}$ at room temperature (RT), affording 7 in an acceptable yield (48\%). Hence, the reaction of the monosubstituted intermediate (i.e., $\mathrm{PhClBC}_{4} \mathrm{~N}_{2} \mathrm{H}_{4} \mathrm{SiMe}_{3}$ ) with $\mathrm{PhBCl}_{2}$ should be much faster than the self-polymerization process. Compounds 3-7 were confirmed by NMR spectroscopic (Figures S1-S15) and HRMS studies. Furthermore, the multinuclear NMR spectroscopic study revealed that the isolated 5-7 all consist of ca. 1:1 cis-trans isomers in the solution phase at ambient temperature due to the nonrotatable $\mathrm{B}=\mathrm{N}$ double bond (see Electronic Supporting Information (ESI)).

Suitable single crystals of $\mathbf{5}$ for X-ray diffraction analysis were obtained by slow evaporation of a saturated hexane solution. Two isomers, $\mathbf{5 a}$ and $\mathbf{5 b}$, co-crystallized in the unit cell. The result is depicted in Figure 1 and Figure S37. The central $\mathrm{C}_{4} \mathrm{~N}_{2}$ ring is nearly planar. The endocyclic N1-C2

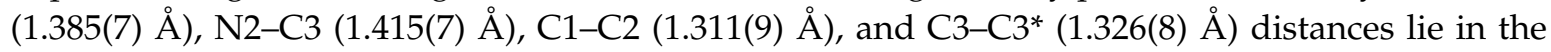
expected range for $\mathrm{N}-\mathrm{C}$ single bonds and $\mathrm{C}=\mathrm{C}$ double bonds. The bond lengths of B1-N1 (1.423(8) $\AA$ ) and B2-N2 (1.400(8) $\AA$ ) are shorter than that of a B-N single bond, which is indicative of a significant $\mathrm{B}=\mathrm{N}$ double bond character. All these geometric parameters suggest the bonding mode $\mathbf{A}$ in Scheme 1 . Therefore, both boron centers adopt a formal oxidation state of +3 . 
<smiles>[R]c1c([R])n([As](C)(C)C)c(C)c(C)c1=O</smiles><smiles>CC(C)(C)O[Na]</smiles>

$1: R=H$ 2: $\mathrm{R}=\mathrm{Me}$

$\mathrm{R}=\mathrm{H} \mid \begin{aligned} & \mathrm{PhBCl}_{2}(2 \mathrm{eq}) \\ & \mathrm{C}_{6} \mathrm{D}_{6}, \mathrm{rt}, 20 \mathrm{~min}\end{aligned}$<smiles>ClB(c1ccccc1)N1C=CN(B(Cl)c2ccccc2)C=C1</smiles>
$7 b$

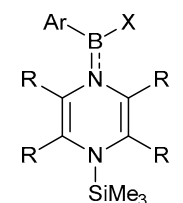

$\underset{\mathrm{C}_{6} \mathrm{D}_{6}, \mathrm{rt} \text {, overnight }}{\stackrel{\mathrm{ArBX}_{2}(1 \text { eq })}{\longrightarrow}}$

$\mathrm{R}=\mathrm{H}, \mathrm{Ar}=\mathrm{Dur}, \mathrm{X}=\mathrm{Br}$ 4: $\mathrm{R}=\mathrm{H}, \mathrm{Ar}=$ Mes, $\mathrm{X}=\mathrm{Cl}$ 8: $\mathrm{R}=\mathrm{Me}, \mathrm{Ar}=\mathrm{Ph}, \mathrm{X}=\mathrm{Cl}$ 9: $\mathrm{R}=\mathrm{Me}, \mathrm{Ar}=\mathrm{Dur}, \mathrm{X}=\mathrm{Br}$

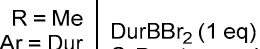
$\begin{array}{rl}\mathrm{Ar}=\mathrm{Dur} & \mathrm{DurBBr} \\ \mathrm{X}=\mathrm{Br} & \mathrm{C}_{6} \mathrm{D}_{6}, \mathrm{rt} \text {, overnight }\end{array}$<smiles>CC1=C(Br)N(B(Br)Br)C(C)=C(Br)N1B(Br)Br</smiles>

$11^{\prime}$

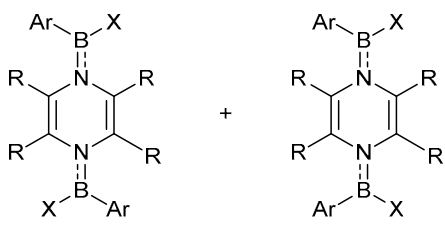

5a: $R=H, A r=D u r, X=B r \quad 5 b: R=H, A r=D u r, X=B r$ $6 a: R=H, A r=$ Mes, $X=C l \quad 6 b: R=H, A r=M e s, X=C l$

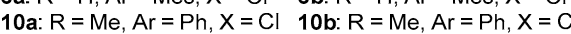

Scheme 2. Synthesis of 3-11.

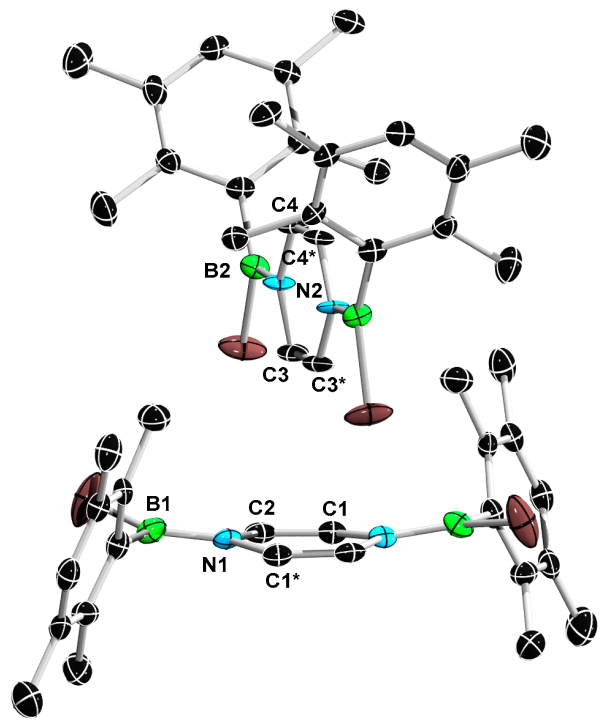

Figure 1. Molecular structures of $\mathbf{5 a}$ (bottom) and $\mathbf{5 b}$ (top) in the solid state (ellipsoids set at $50 \%$ probability). Hydrogen atoms are omitted for clarity. Selected bond lengths $(\AA)$ and angles $\left({ }^{\circ}\right)$ for 5a: B1-N1 1.423(8), N1-C2 1.385(7), C1-C2 1.311(9), C1-C2-N1 123.1(5), C2-N1-C1* 113.9(4); for 5b: B2-N2 1.400(8), N2-C4 1.411(6), N2-C3 1.415(7), C4-C4* 1.328(8), C3-C3* 1.326(8), C4*-C4-N2 123.7(4), C4-N2-C3 112.6(4), N2-C3-C3* 123.7(5).

Compound 2, which features a less-negative redox potential $(+0.10 \mathrm{~V})$ with respect to $1(-0.24 \mathrm{~V})$, was further examined to reduce $\mathrm{PhBCl}_{2}$ and $\mathrm{DurBBr}_{2}$ (Scheme 2). Differing from the aforementioned reactions with $\mathbf{1}$, both monosubstituted products 8 and 9 could be prepared upon a 1:1 ratio reaction of 2 with $\mathrm{PhBCl}_{2}$ and $\mathrm{DurBBr}_{2}$, respectively. Upon the reaction of 2 with two equiv. of $\mathrm{PhBCl}_{2}$ at RT, the disubstituted compounds $\mathbf{1 0 a}$ and $\mathbf{1 0 b}$ were obtained as 1:1 cis-trans isomers. Surprisingly, treatment of 2 with two equiv. of $\mathrm{DurBBr}_{2}$ at ambient temperature led to the formation of $\mathbf{1 1}$, which can be regarded as the product from an isomerization of $\mathbf{1 1}^{\prime}$ [36,37]. Compounds $\mathbf{8 - 1 1}$ were confirmed by NMR spectroscopic (Figures S16-S28) and HRMS studies. There were two sets (intensity ratio of ca. 1:0.3) of ${ }^{1} \mathrm{H}$ signals between 4 and $6 \mathrm{ppm}$, each consisting of three multiplets with the integration ratio of 1:1:1, which can be assigned to the migrated $\mathrm{H}$ and two remaining olefinic protons. These are the 
most characteristic signs for the formation of the isomerized product. After assigning each peak (with the help of the NOE spectrum, see the ESI Figure S26 for more details), we could determine that the ratio of isomers $\mathbf{1 1 a}$ and $\mathbf{1 1 b}$ was 77:23. Furthermore, the isomerization was also observed upon the treatment of the isolated 9 with an equimolar amount of $\operatorname{DurBBr}_{2}$ at RT.

The structures of $\mathbf{9}, \mathbf{1 0 a}, \mathbf{1 1 a}$, and $\mathbf{1 1 b}$ were confirmed by single-crystal X-ray diffraction analysis (Figure 2 and Figures S38-S40). All four compounds adopt a boat conformation, which could be explained by the small energy difference between the planar and nonplanar geometry of the $\mathrm{C}_{4} \mathrm{~N}_{2}$ ring, and the steric congestion between the central exocyclic methyl groups and the bulky boron substituents. Bond lengths ( $\AA$ ) of 9 (B1-N1 1.376(7), N1-C1 1.451(6), C1-C2 1.343(7), N2-C2 1.434(6), N2-Si1 1.759(5)), 10 (B1-N1 1.401(2), N1-C2 1.4494(17), C1-C2 1.328(2), N1-C1*1.4513(18)) are all as expected. The overall structures of $\mathbf{1 1 a}$ and $\mathbf{1 1 b}$ resemble that of 10a. However, since the C3 position in 11a and $11 \mathbf{b}$ accepted one $\mathrm{H}$ atom from the methyl group at the $\mathrm{C} 2$ position, respectively, and thus became $s p^{3}$-hybridized, the torsion angles C4-C3-N2-B2 (11a: $94.25^{\circ} ; \mathbf{1 1 b}$ : $\left.94.69^{\circ}\right)$ are notably greater than those at the other three carbon positions $\left(57-63^{\circ}\right)$ in the central six-membered ring. Due to the disordered nature of the crystal, the bond lengths of $\mathbf{1 1 a}$ and $\mathbf{1 1} \mathbf{b}$ cannot be further discussed.



9

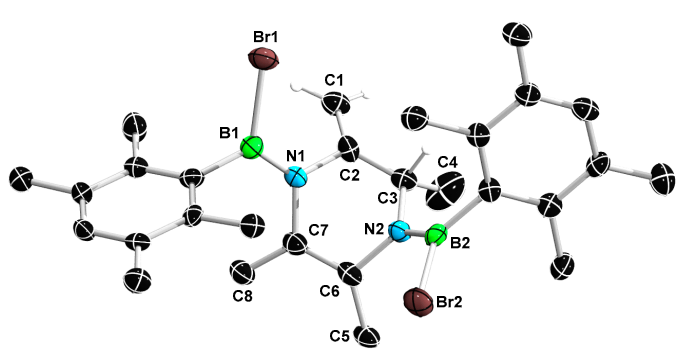

$11 \mathrm{a}$

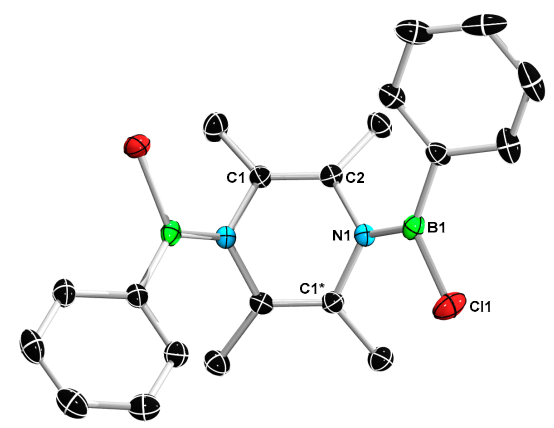

10a

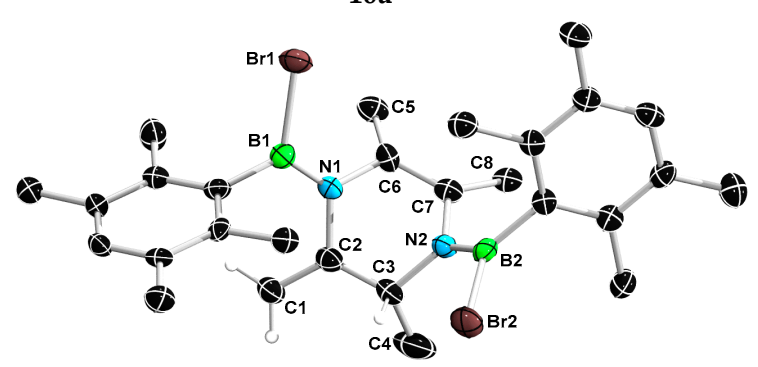

$11 b$

Figure 2. Molecular structures of 9, 10a, and 11 in the solid state (ellipsoids set at 50\% probability). Hydrogen atoms, except for the $\mathrm{C}\left(\mathrm{sp}^{3}\right)-\mathrm{H}$ and the olefinic $\mathrm{H}$ in 11a and 11b, are omitted for clarity. Selected bond lengths $(\AA)$ and angles $\left(^{\circ}\right)$ for 9: B1-N1 1.376(7), N1-C1 1.451(6), C1-C2 1.343(7), N2-C2 1.434(6), N2-Si1 1.759(5), C2-C1-N1 115.3(4), C1-N1-C1* 111.1(4); for 10a: B1-N1 1.401(2), N1-C2 1.4494(17), C1-C2 1.328(2), N1-C1*1.4513(18), C1-C2-N1 116.25(12), C2-N1-C1* 110.63(11).

The reaction of $\left(\mathrm{SiMe}_{3}\right)_{2} \mathrm{NBCl}_{2}$ with 12 [38] of greater reducing power (redox potential of $-0.40 \mathrm{~V}$ ) [39] was performed at ambient temperature in $\mathrm{C}_{6} \mathrm{D}_{6}$. After the removal of the solvent and extraction with hexane, an NMR spectroscopically pure product $\mathbf{1 3}$ was obtained with a yield of $75 \%$. Compound 13 was confirmed by NMR spectroscopic (Figures S29-S31) and HRMS studies. Suitable single crystals of 13a for X-ray diffraction analysis were obtained upon storage of the reaction mixture overnight at RT (Figure 3 and Figure S41). The N1-C1/N1-C5 (1.402(8)-1.414(8) A), C1-C2/C5-C4

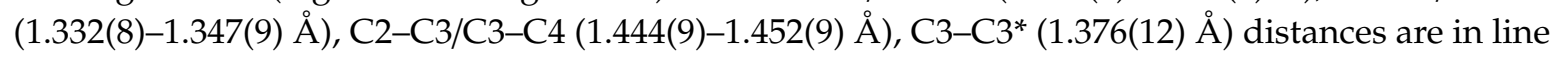
with the Lewis structure depicted in Scheme 3. 


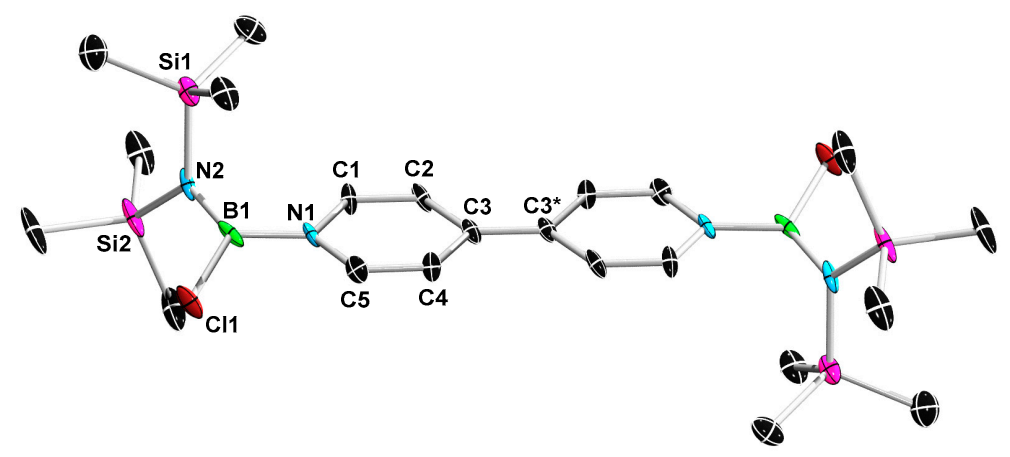

Figure 3. Molecular structure of 13a in the solid state (ellipsoids set at 50\% probability). Selected bond lengths $(\AA)$ and angles $\left({ }^{\circ}\right)$ for 13a: B1-N1 1.459(8), B1-N2 1.392(10), Si1-N2 1.757(5), Si2-N2 1.770(5), N1-C1 1.402(8), N1-C5 1.414(8), C1-C2 1.332(8), C4-C5 1.347(9), C2-C3 1.452(9), C3-C4 1.444(9), C3-C3* 1.376(12), C1-N1-C5 115.7(5), C2-C1-N1 123.3(6), C1-C2-C3 122.9(6), C4-C3-C2 112.7(5), C5-C4-C3 123.3(6), C4-C5-N1 122.1(6).

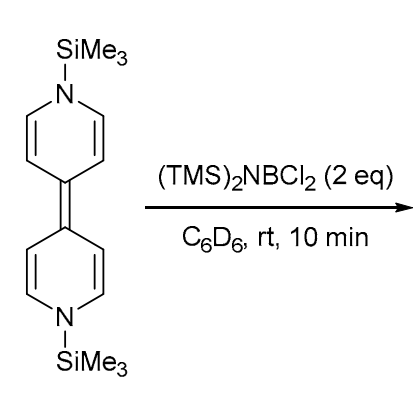

12

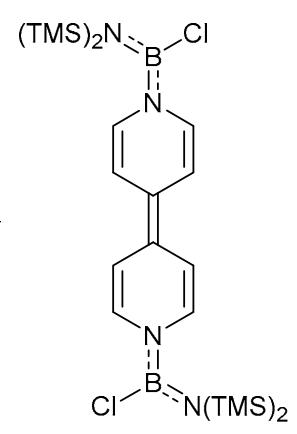

$13 a$



Scheme 3. Synthesis of 13 .

Apparently, both the RT-NMR spectroscopic and crystallographic studies failed to prove any successful reduction of the trivalent borane to divalent boron radical. Since the rotational barrier around an $\mathrm{N}-\mathrm{B}$ dative bond should be lower than that of a $\mathrm{B}=\mathrm{N}$ double bond, we assumed that any contribution from the bonding mode $\mathbf{B}$ (Scheme 1) should slightly lower the rotational barrier around the exocyclic B-N bond. In this context, we conducted a variable-temperature ${ }^{1} \mathrm{H}-\mathrm{NMR}$ experiment to provide further insight. Toluene- $\mathrm{d}^{8}$ was selected as the solvent with a temperature ranging from $-60^{\circ} \mathrm{C}$ to $80^{\circ} \mathrm{C}$. In general, the exocyclic $\mathrm{H}$ or Me as marked in Figure 4 (top right) should display two signals if the $\mathrm{B}=\mathrm{N}$ bond is nonrotatable. The separated signals will coalesce at an elevated temperature when the $\mathrm{B}-\mathrm{N}$ bond overcomes the rotational barrier and begins to rotate. Determination of the separation $(\mathrm{Hz})$ of two signals and the coalescent temperature allows calculation of the $\mathrm{B}-\mathrm{N}$ rotational barrier. The results of the VT-NMR experiments and assignment of the signals of interest are depicted in Figure 4 and Figures S32-S36. The obtained $\Delta G^{\neq}$values are summarized in Table 1 . Analysis of the VT-NMR spectra revealed 7 with a strong $\mathrm{B}=\mathrm{N}$ bond, and $\mathbf{1 0}$ and $\mathbf{1 3}$ with weak $\mathrm{B}=\mathrm{N}$ bonds, as reflected by their rotational barriers $>71.56 \mathrm{~kJ} / \mathrm{mol}$ (7), $58.79 \mathrm{~kJ} / \mathrm{mol}$ (10), $58.65 \mathrm{~kJ} / \mathrm{mol}$ (13) when compared with ordinary $\mathrm{B}=\mathrm{N}$ double bonds $(71-100 \mathrm{~kJ} / \mathrm{mol})$ [40]. When taking the aforementioned assumption into account, the remarkably lower B-N rotational barrier of $\mathbf{1 0}$ compared to that of $\mathbf{7}$ is not in line with the fact that the reducing power of $\mathbf{2}$ is slightly weaker than that of $\mathbf{1}$, according to the $\mathrm{CV}$ data. Therefore, the lower B-N rotational barrier in $\mathbf{1 0}$ should be mainly due to its boat conformation, which allows for less steric hindrance. Furthermore, although the central $\mathrm{C}_{4} \mathrm{~N}_{2}$ rings of 7 and $\mathbf{1 3}$ both adopt a planar structure, the $\mathrm{B}-\mathrm{N}$ rotational barrier in $\mathbf{1 3}$ is significantly lower than that of $\mathbf{7}$. This finding could be explained by the competition in $\pi$ donation from another $B$-amino function $\left(-\mathrm{N}\left(\mathrm{SiMe}_{3}\right)_{2}\right)$ in 13 . 


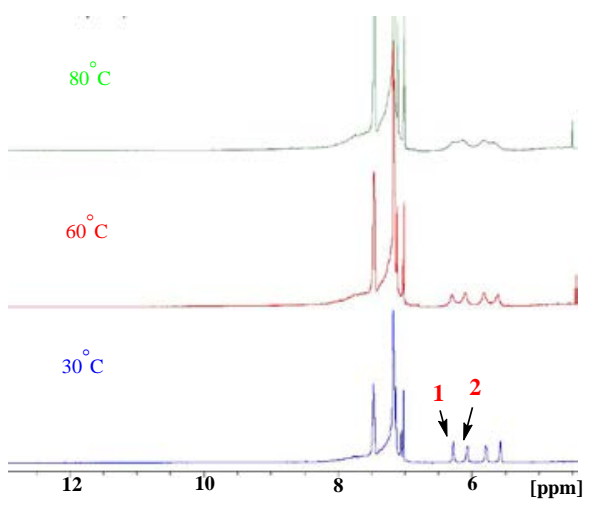

(7)
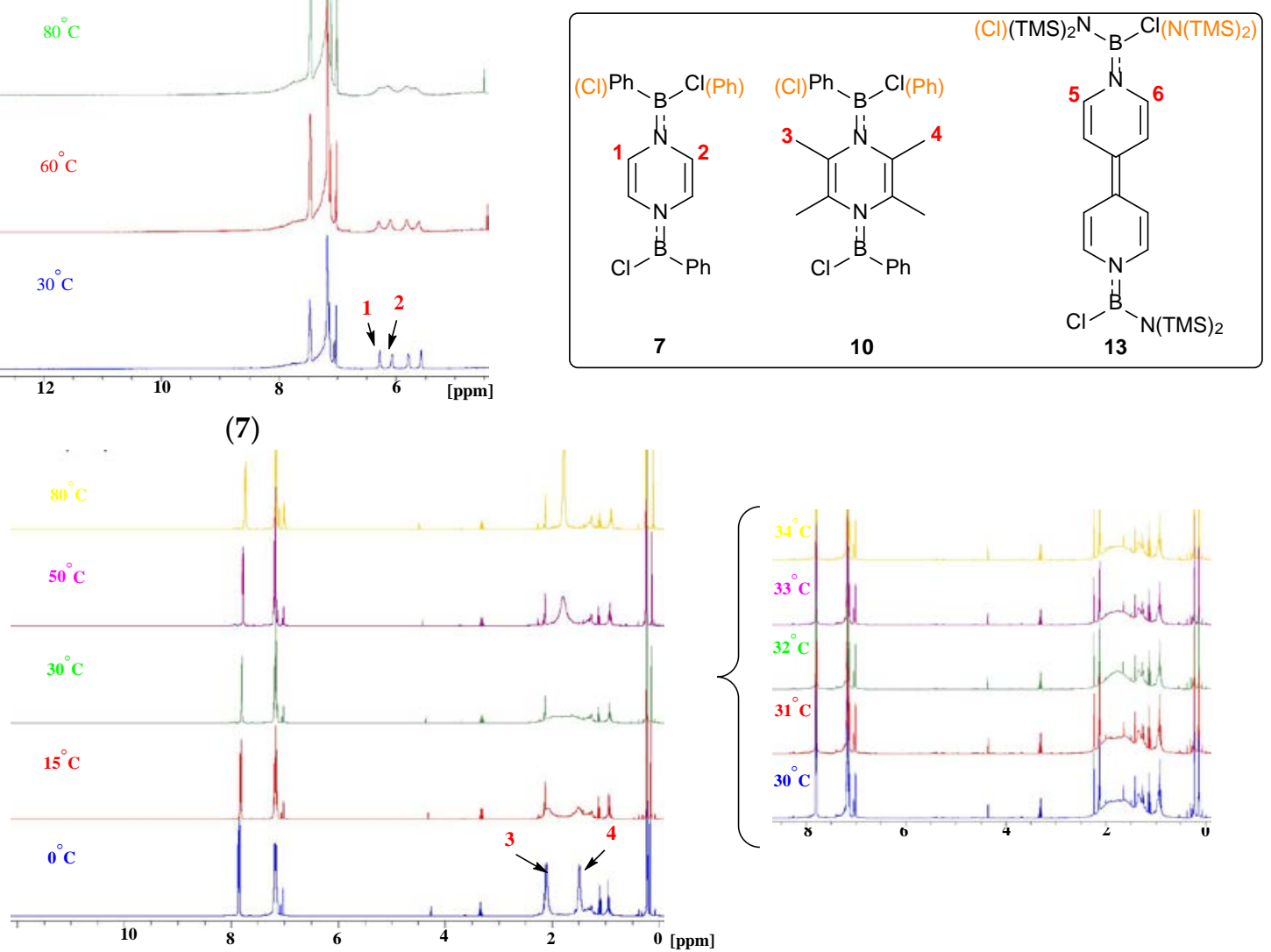

(10)
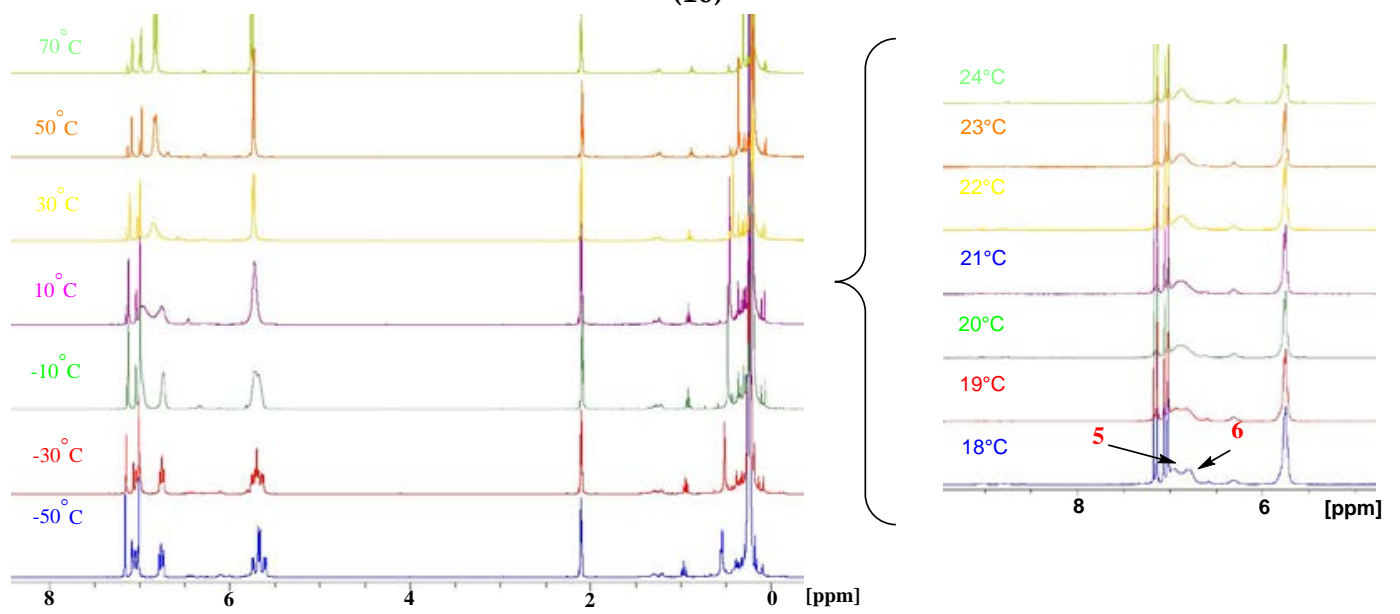

(13)

Figure 4. Variable-temperature ${ }^{1} \mathrm{H}-\mathrm{NMR}\left(400 \mathrm{MHz}\right.$, toluene-d $\left.{ }^{8}\right)$ spectra of 7, 10, and 13.

Table 1. Rotational barrier of 7, 10, and 13 .

\begin{tabular}{cccc}
\hline Compound & Tc & $\Delta \boldsymbol{v}$ & $\Delta \mathbf{G}^{\neq}$ \\
\hline $\mathbf{7}$ & $>80^{\circ} \mathrm{C}(353 \mathrm{~K})$ & $85.0 \mathrm{~Hz}$ & $>71.56 \mathrm{~kJ} / \mathrm{mol}$ \\
$\mathbf{1 0}$ & $32^{\circ} \mathrm{C}(305 \mathrm{~K})$ & $243.5 \mathrm{~Hz}$ & $58.79 \mathrm{~kJ} / \mathrm{mol}$ \\
$\mathbf{1 3}$ & $20^{\circ} \mathrm{C}(293 \mathrm{~K})$ & $96.0 \mathrm{~Hz}$ & $58.65 \mathrm{~kJ} / \mathrm{mol}$
\end{tabular}

$\mathrm{Tc}=$ coalescence temperature; $\Delta v=$ the separation in hertz between the two singlets in the absence of exchange; $\Delta \mathbf{G}^{\neq}=$rotational barrier. 


\section{Materials and Methods}

\subsection{General Information}

All manipulations were performed under dry argon using standard Schlenk line or glovebox techniques. Solvents were purified by distillation from $\mathrm{Na}$ under dry argon. $\mathrm{C}_{6} \mathrm{D}_{6}$ was dried over an $\mathrm{Na} / \mathrm{K}$ alloy and then degassed by freeze-pump-thaw cycles. $\mathrm{PhBCl}_{2}$ was purchased from Beijing MREDA Technologie Co., Ltd., without any special treatment before use. The NMR spectra were acquired on a Bruker AVANCE $400\left({ }^{1} \mathrm{H}: 400 \mathrm{MHz},{ }^{13} \mathrm{C}\left\{{ }^{1} \mathrm{H}\right\}: 101 \mathrm{MHz},{ }^{11} \mathrm{~B}: 128 \mathrm{MHz}\right) \mathrm{NMR}$ spectrometer at $298 \mathrm{~K}$. Variable-temperature NMR experiments were conducted on a Bruker AVANCE 400 NMR spectrometer $\left({ }^{1} \mathrm{H}: 400 \mathrm{MHz}, 213-353 \mathrm{~K}\right)$. Chemical shifts are given in ppm. ${ }^{1} \mathrm{H}$ and ${ }^{13} \mathrm{C}\left\{{ }^{1} \mathrm{H}\right\} \mathrm{NMR}$ spectra were referenced to an external tetramethylsilane (TMS) via the residual protons of the solvent $\left({ }^{1} \mathrm{H}\right)$ or the solvent itself $\left({ }^{13} \mathrm{C}\left\{{ }^{1} \mathrm{H}\right\}\right)$. ${ }^{11} \mathrm{~B} \mathrm{NMR}$ spectra were referenced to the external $\mathrm{BF}_{3} \cdot \mathrm{OEt}_{2}$. High-resolution mass spectrometry (HMRS) was performed with a Thermo Fisher Scientific $Q$ Exactive Mass Spectrometer (MS) system.

\subsection{Synthesis of 3 and 4 :}

In the glove box, $\operatorname{DurBBr}_{2}(30.3 \mathrm{mg}, 0.1 \mathrm{mmol}, 1.0$ equiv.) and 1,4-bis(trimethylsilyl)-1,4-diaza2,5-cyclohexadiene (1) (22.6 mg, $0.1 \mathrm{mmol}, 1.0$ equiv.) were added into $\mathrm{C}_{6} \mathrm{D}_{6}(0.6 \mathrm{~mL})$ in a J. Young NMR tube. The mixture was rested for $10 \mathrm{~min}$ prior to the removal of the volatiles under vacuum to get 3 as a pale yellow solid (23.6 mg, $72 \mathrm{mmol}, 63 \%)$. Compound 4 was synthesized in a similar manner, with a yield of $64 \%$.

3: ${ }^{1} \mathrm{H}-\mathrm{NMR}\left(400 \mathrm{MHz}, \mathrm{C}_{6} \mathrm{D}_{6}\right): \delta=6.86\left(\mathrm{~s}, 1 \mathrm{H}, \mathrm{H}\right.$ of Dur), $6.35\left(\mathrm{~d}, J=6.6 \mathrm{~Hz}, 1 \mathrm{H}, \mathrm{H}\right.$ of $\left.\mathrm{C}_{4} \mathrm{~N}_{2}\right), 5.13(\mathrm{~d}$, $J=6.5 \mathrm{~Hz}, 1 \mathrm{H}, \mathrm{H}$ of $\left.\mathrm{C}_{4} \mathrm{~N}_{2}\right), 4.91\left(\mathrm{~d}, J=6.6 \mathrm{~Hz}, 1 \mathrm{H}, \mathrm{H}\right.$ of $\left.\mathrm{C}_{4} \mathrm{~N}_{2}\right), 4.64\left(\mathrm{~d}, J=6.5 \mathrm{~Hz}, 1 \mathrm{H}, \mathrm{H}\right.$ of $\left.\mathrm{C}_{4} \mathrm{~N}_{2}\right)$, 2.29 (s, 6H, Me of Dur), 2.06 (s, 6H, Me of Dur), -0.23 (s, 9H, Me of TMS). ${ }^{13} \mathrm{C}\left\{{ }^{1} \mathbf{H}\right\}-\mathbf{N M R}(101 \mathrm{MHz}$, $\left.\mathrm{C}_{6} \mathrm{D}_{6}\right): \delta=134.5,133.4,132.0,119.8,118.7,113.5,112.8,19.4,18.4,-2.3$ (9C, C of TMS). The carbon atom directly attached to boron was not detected, likely due to quadrupolar broadening. ${ }^{11} \mathbf{B}-\mathbf{N M R}$ (128 MHz, $\left.\mathrm{C}_{6} \mathrm{D}_{6}\right): \delta=34.1$. HRMS: calc. for $[\mathrm{M}]^{+} \mathrm{C}_{17} \mathrm{H}_{26} \mathrm{BBrN}_{2} \mathrm{Si}^{+}$376.11362; found: 376.11308 .

4: ${ }^{1} \mathrm{H}-\mathrm{NMR}\left(400 \mathrm{MHz}, \mathrm{C}_{6} \mathrm{D}_{6}\right): \delta=6.75\left(\mathrm{~s}, 2 \mathrm{H}, \mathrm{H}\right.$ of Mes), $6.17\left(\mathrm{~d}, J=6.6 \mathrm{~Hz}, 1 \mathrm{H}, \mathrm{H}\right.$ of $\left.\mathrm{C}_{4} \mathrm{~N}_{2}\right), 5.07$ $\left(\mathrm{d}, J=6.5 \mathrm{~Hz}, 1 \mathrm{H}, \mathrm{H}\right.$ of $\left.\mathrm{C}_{4} \mathrm{~N}_{2}\right), 4.91\left(\mathrm{~d}, J=6.6 \mathrm{~Hz}, 1 \mathrm{H}, \mathrm{H}\right.$ of $\left.\mathrm{C}_{4} \mathrm{~N}_{2}\right), 4.65\left(\mathrm{~d}, J=6.5 \mathrm{~Hz}, 1 \mathrm{H}, \mathrm{H}\right.$ of $\left.\mathrm{C}_{4} \mathrm{~N}_{2}\right)$, 2.37 (s, 6H, Me of Mes), 2.15 (s, 3H, Me of Mes), 0.21 (s, 9H, Me of TMS). ${ }^{13} \mathrm{C}\left\{{ }^{1} \mathbf{H}\right\}-\mathbf{N M R}(101 \mathrm{MHz}$, $\left.\mathrm{C}_{6} \mathrm{D}_{6}\right): \delta=139.2,137.8,127.5,119.4,118.5,112.4\left(1 \mathrm{C}, \mathrm{C}\right.$ of $\left.\mathrm{C}_{4} \mathrm{~N}_{2}\right), 112.8\left(1 \mathrm{C}, \mathrm{C}\right.$ of $\left.\mathrm{C}_{4} \mathrm{~N}_{2}\right), 21.3\left(2 \mathrm{C}, o-\mathrm{CH}_{3}\right.$ of Mes), 20.9 (C, $p-\mathrm{CH}_{3}$ of Mes), -2.3 (9C, C of TMS). The carbon atom directly attached to boron was not detected, likely due to quadrupolar broadening. ${ }^{11} \mathbf{B}-\mathrm{NMR}\left(128 \mathrm{MHz}, \mathrm{C}_{6} \mathrm{D}_{6}\right): \delta=34.2$. HRMS: calc. for $[\mathrm{M}]^{+} \mathrm{C}_{16} \mathrm{H}_{24} \mathrm{BClN}_{2} \mathrm{Si}^{+} 318.14848$; found: 318.14877 .

\subsection{Synthesis of $5-7$}

In the glove box, $\operatorname{DurBBr}_{2}(60.4 \mathrm{mg}, 0.2 \mathrm{mmol}, 2.0$ equiv.) and 1,4-bis(trimethylsilyl)-1,4-diaza2,5-cyclohexadiene (1) (22.6 mg, $0.1 \mathrm{mmol}, 1.0$ equiv.) were added into $\mathrm{C}_{6} \mathrm{D}_{6}(0.6 \mathrm{~mL})$ in a J. Young NMR tube. The mixture was rested overnight prior to the removal of the volatiles under vacuum to get 5 as a yellow oil with a $45 \%$ yield. Mixture 5 contains the cis-structure $5 \mathbf{a}$ and trans-structure $5 \mathbf{b}$, and the ratio of the cis-trans isomers was about 1:1. Compounds 6-7 were synthesized in a similar manner, with a cis-trans isomers ratio of about $1: 1$ (yield: $52 \%(6)$ and $48 \%(7)$ ].

$5 \mathbf{a}+5 \mathbf{b}:{ }^{1} \mathrm{H}-\mathrm{NMR}\left(400 \mathrm{MHz}, \mathrm{C}_{6} \mathrm{D}_{6}\right): \delta=6.86(\mathrm{~s}, 2 \mathrm{H}), 6.82(\mathrm{~s}, 2 \mathrm{H}), 6.52(\mathrm{~s}, 2 \mathrm{H}), 6.26\left(\mathrm{~d},{ }^{3} J_{\mathrm{H}-\mathrm{H}}=1.6 \mathrm{~Hz}\right.$, $1 \mathrm{H}), 6.24\left(\mathrm{~d},{ }^{3} J_{\mathrm{H}-\mathrm{H}}=1.6 \mathrm{~Hz}, 1 \mathrm{H}\right), 5.36\left(\mathrm{~d},{ }^{3} J_{\mathrm{H}-\mathrm{H}}=1.6 \mathrm{~Hz}, 1 \mathrm{H}\right), 5.34\left(\mathrm{~d},{ }^{3} J_{\mathrm{H}-\mathrm{H}}=1.6 \mathrm{~Hz}, 1 \mathrm{H}\right), 4.99(\mathrm{~s}, 2 \mathrm{H})$, 2.09 (s, $12 \mathrm{H}), 2.07$ (s, $12 \mathrm{H}), 2.03(\mathrm{~s}, 12 \mathrm{H}), 2.01(\mathrm{~s}, 12 \mathrm{H}) .{ }^{13} \mathrm{C}\left\{{ }^{1} \mathbf{H}\right\}-\mathbf{N M R}\left(101 \mathrm{MHz}, \mathrm{C}_{6} \mathrm{D}_{6}\right): \delta=134.0$, $133.9,133.6,133.5,132.5,132.3,118.2,117.7,117.2,116.6,19.2,19.1,18.5,18.4$. The carbon atom directly attached to boron was not detected, likely due to quadrupolar broadening. ${ }^{11} \mathbf{B}-\mathbf{N M R}\left(128 \mathrm{MHz}, \mathrm{C}_{6} \mathrm{D}_{6}\right)$ : $\delta=38.9$. HRMS: calc. for $[\mathrm{M}]^{+} \mathrm{C}_{24} \mathrm{H}_{30} \mathrm{~N}_{2} \mathrm{~B}_{2} \mathrm{Br}_{2}{ }^{+}$526.09564; found: 526.09549 .

6a + 6b: ${ }^{1} \mathrm{H}-\mathrm{NMR}\left(400 \mathrm{MHz}, \mathrm{C}_{6} \mathrm{D}_{6}\right): \delta=6.69(\mathrm{~s}, 4 \mathrm{H}), 6.67(\mathrm{~s}, 4 \mathrm{H}), 6.34(\mathrm{~s}, 2 \mathrm{H}), 6.09\left(\mathrm{~d},{ }^{3} \mathrm{~J}_{\mathrm{H}-\mathrm{H}}=1.6 \mathrm{~Hz}\right.$, $1 \mathrm{H}), 6.08\left(\mathrm{~d},{ }^{3} J_{\mathrm{H}-\mathrm{H}}=1.6 \mathrm{~Hz}, 1 \mathrm{H}\right), 5.32\left(\mathrm{~d},{ }^{3} J_{\mathrm{H}-\mathrm{H}}=1.6 \mathrm{~Hz}, 1 \mathrm{H}\right), 5.30\left(\mathrm{~d},{ }^{3} J_{\mathrm{H}-\mathrm{H}}=1.6 \mathrm{~Hz}, 1 \mathrm{H}\right), 4.94(\mathrm{~s}$, 
2H), $\left.2.19(\mathrm{~s}, 12 \mathrm{H}), 2.16(\mathrm{~s}, 12 \mathrm{H}), 2.13(\mathrm{~s}, 6 \mathrm{H}), 2.12(\mathrm{~s}, 6 \mathrm{H}) .{ }^{13} \mathrm{C}^{1}{ }^{1} \mathrm{H}\right\}-\mathrm{NMR}\left(101 \mathrm{MHz}, \mathrm{C}_{6} \mathrm{D}_{6}\right): \delta=138.9$, $138.8,138.6,138.5,127.6,127.6,117.3,116.4,116.3,115.5,21.2,21.1,20.9,20.8$. The carbon atom directly attached to boron was not detected, likely due to quadrupolar broadening. ${ }^{11} \mathbf{B}-\mathbf{N M R}\left(128 \mathrm{MHz}, \mathrm{C}_{6} \mathrm{D}_{6}\right)$ : $\delta=38.5$. HRMS: calc. for $[\mathrm{M}]^{+} \mathrm{C}_{22} \mathrm{H}_{26} \mathrm{~N}_{2} \mathrm{~B}_{2} \mathrm{Cl}^{+}$410.16537; found: 410.16492 .

7a + 7b: ${ }^{1} \mathrm{H}-\mathrm{NMR}\left(400 \mathrm{MHz}, \mathrm{C}_{6} \mathrm{D}_{6}\right): \delta=7.86(\mathrm{~s}, 2 \mathrm{H}), 7.51-7.46(\mathrm{~m}, 8 \mathrm{H}), 7.19-7.15(\mathrm{~m}, 10 \mathrm{H})$, $6.29(\mathrm{~s}, 2 \mathrm{H}), 6.08\left(\mathrm{~d},{ }^{3} J_{\mathrm{H}-\mathrm{H}}=1.68 \mathrm{~Hz}, 1 \mathrm{H}\right), 6.06\left(\mathrm{~d},{ }^{3} J_{\mathrm{H}-\mathrm{H}}=1.64 \mathrm{~Hz}, 1 \mathrm{H}\right), 5.78\left(\mathrm{~d},{ }^{3} J_{\mathrm{H}-\mathrm{H}}=1.60 \mathrm{~Hz}, 1 \mathrm{H}\right)$, $5.76\left(\mathrm{~d},{ }^{3} J_{\mathrm{H}-\mathrm{H}}=1.70 \mathrm{~Hz}, 1 \mathrm{H}\right), 5.54(\mathrm{~s}, 2 \mathrm{H}) .{ }^{13} \mathrm{C}\left\{{ }^{1} \mathrm{H}\right\}-\mathrm{NMR}\left(101 \mathrm{MHz}, \mathrm{C}_{6} \mathrm{D}_{6}\right): \delta=133.3,133.2,130.2,130.1$, $127.9,127.8,118.0,117.5,116.8,116.5$. The carbon atom directly attached to boron was not detected, likely due to quadrupolar broadening. ${ }^{11}$ B-NMR $\left(128 \mathrm{MHz}, \mathrm{C}_{6} \mathrm{D}_{6}\right): \delta=36.5$. HRMS: calc. for $[\mathrm{M}]^{+}$ $\mathrm{C}_{16} \mathrm{H}_{14} \mathrm{~N}_{2} \mathrm{~B}_{2} \mathrm{Cl}_{2}+326.07147$; found: 326.07069 .

\subsection{Synthesis of 8 and 9}

Compounds 8 and 9 were synthesized in a similar manner as 3 and 4 , with yields of $65 \%$ and $75 \%$, respectively.

8: ${ }^{1} \mathrm{H}-\mathrm{NMR}\left(400 \mathrm{MHz}, \mathrm{C}_{6} \mathrm{D}_{6}\right): \delta=7.93-7.90(\mathrm{~m}, 2 \mathrm{H}), 7.85-7.83(\mathrm{~m}, 1 \mathrm{H}), 7.24-7.13(\mathrm{~m}, 2 \mathrm{H}), 2.14$ (s, 3H), $\left.1.68(\mathrm{~s}, 3 \mathrm{H}), 1.62(\mathrm{~s}, 3 \mathrm{H}), 1.52(\mathrm{~s}, 3 \mathrm{H}), 0.19(\mathrm{~s}, 9 \mathrm{H}) .{ }^{13} \mathrm{C}^{1}{ }^{1} \mathrm{H}\right\}-\mathrm{NMR}\left(101 \mathrm{MHz}, \mathrm{C}_{6} \mathrm{D}_{6}\right): \delta=132.5$, $132.2,131.9,131.9,131.6,128.6,128.0,122.8,121.8,16.8,16.7,16.7,16.5,0.2$. The carbon atom directly attached to boron was not detected, likely due to quadrupolar broadening. ${ }^{11} \mathbf{B}-\mathbf{N M R}\left(128 \mathrm{MHz}, \mathrm{C}_{6} \mathrm{D}_{6}\right)$ : $\delta=35.9$. HRMS: calc. for $[\mathrm{M}+\mathrm{H}]^{+} \mathrm{C}_{17} \mathrm{H}_{27} \mathrm{~N}_{2} \mathrm{BClSi}^{+}$333.17196; found: 333.17233 .

9: ${ }^{1} \mathrm{H}-\mathrm{NMR}\left(400 \mathrm{MHz}, \mathrm{C}_{6} \mathrm{D}_{6}\right): \delta=6.88(\mathrm{~s}, 1 \mathrm{H}), 2.43(\mathrm{~s}, 3 \mathrm{H}), 2.29(\mathrm{~s}, 3 \mathrm{H}), 2.24(\mathrm{~s}, 3 \mathrm{H}, \mathrm{Me}$ of Dur), $2.10(\mathrm{~s}, 3 \mathrm{H}), 2.06(\mathrm{~s}, 3 \mathrm{H}), 1.71(\mathrm{~s}, 3 \mathrm{H}), 1.48(\mathrm{~s}, 3 \mathrm{H}), 1.44(\mathrm{~s}, 3 \mathrm{H}), 0.25(\mathrm{~s}, 9 \mathrm{H}) .{ }^{13} \mathrm{C}\left\{{ }^{1} \mathrm{H}\right\}-\mathrm{NMR}(101 \mathrm{MHz}$, $\left.\mathrm{C}_{6} \mathrm{D}_{6}\right): \delta=133.8,133.2,133.1,133.0,132.8,131.6,131.4,122.5,122.0,19.6,19.4,19.3,19.3,19.2,18.1$, 18.0, 16.1, 1.8. The carbon atom directly attached to boron was not detected, likely due to quadrupolar broadening. ${ }^{11}$ B-NMR $\left(128 \mathrm{MHz}, \mathrm{C}_{6} \mathrm{D}_{6}\right): \delta=37.7$. HRMS: calc. for $[\mathrm{M}+\mathrm{H}]^{+} \mathrm{C}_{21} \mathrm{H}_{35} \mathrm{~N}_{2} \mathrm{BBrSi}^{+}$ 433.18405; found: 433.18483.

\subsection{Synthesis of $\mathbf{1 0}$}

In the glove box, $\mathrm{PhBCl}_{2}$ (31.6 mg, $0.2 \mathrm{mmol}, 2.0$ equiv.) and 2,3,5,6-tetramethyl1,4-bis(trimethylsilyl)-1,4-diaza-2,5-cyclohexadiene (2) (28.2 mg, $0.1 \mathrm{mmol}, 1.0$ equiv.) were added into $\mathrm{C}_{6} \mathrm{D}_{6}(0.6 \mathrm{~mL})$ in a J. Young NMR tube. The mixture was rested overnight prior to the removal of the volatiles under vacuum to get $\mathbf{1 0}$ as a pale yellow solid $(24.9 \mathrm{mg}, 0.53 \mathrm{mmol}, 53 \%)$.

10a + 10b: ${ }^{1} \mathrm{H}-\mathrm{NMR}\left(400 \mathrm{MHz}\right.$, toluene-d $\left.{ }^{8}\right): \delta=7.72-7.20(\mathrm{~m}, 8 \mathrm{H}), 7.11-7.06(\mathrm{~m}, 12 \mathrm{H}), 1.95(\mathrm{br}$, 12H), 1.45 (br, 12H). $\left.{ }^{13} \mathrm{C}^{1}{ }^{1} \mathrm{H}\right\}$-NMR (101 MHz, toluene-d $\left.{ }^{8}\right): \delta=133.2,130.2,129.1,128.6,128.2,128.0$, $127.9,127.7,125.4,124.9,20.8,20.7,20.3,20.1$. The carbon atom directly attached to boron was not detected, likely due to quadrupolar broadening. ${ }^{11} \mathbf{B}-\mathbf{N M R}\left(128 \mathrm{MHz}\right.$, toluene- $\left.\mathrm{d}^{8}\right)$ : $\delta=36.9$. HRMS: calc. for $[\mathrm{M}+\mathrm{H}]^{+} \mathrm{C}_{20} \mathrm{H}_{23} \mathrm{~N}_{2} \mathrm{~B}_{2} \mathrm{Cl}_{2}{ }^{+}$383.14189; found: 383.14083 .

\subsection{Synthesis of $\mathbf{1 1 a}$ and $\mathbf{1 1 b}$}

In the glove box, 9 (37.6 mg, $0.1 \mathrm{mmol}, 1$ equiv.) and $\mathrm{DurBBr}_{2}(30.3 \mathrm{mg}, 1 \mathrm{mmol}, 1.0$ equiv.) were added into $\mathrm{C}_{6} \mathrm{D}_{6}(0.6 \mathrm{~mL})$ in a J. Young NMR tube. The mixture was rested overnight prior to the removal of the volatiles under vacuum to get $\mathbf{1 1}$ as a yellow oil with a yield of $76 \%$. Mixture 11 contains two olefin isomers, $\mathbf{1 1} \mathbf{a}$ and $\mathbf{1 1} \mathbf{b}$, with a ratio of about 1:0.3.

11a: ${ }^{1} \mathrm{H}-\mathrm{NMR}\left(400 \mathrm{MHz}, \mathrm{C}_{6} \mathrm{D}_{6}\right): \delta=6.91(\mathrm{~s}, 1 \mathrm{H}), 6.89(\mathrm{~s}, 1 \mathrm{H}), 5.14-5.13(\mathrm{~m}, 1 \mathrm{H}), 4.72-4.71(\mathrm{~m}, 1 \mathrm{H})$, $4.38(\mathrm{~s}, 1 \mathrm{H}), 2.58(\mathrm{~s}, 3 \mathrm{H}), 2.55(\mathrm{~s}, 3 \mathrm{H}), 2.35(\mathrm{~s}, 3 \mathrm{H}), 2.32(\mathrm{~s}, 3 \mathrm{H}), 2.11(\mathrm{~s}, 3 \mathrm{H}), 2.09(\mathrm{~s}, 6 \mathrm{H}), 2.07(\mathrm{~s}, 3 \mathrm{H}), 1.99$ $\left(\mathrm{d},{ }^{3} J_{\mathrm{H}-\mathrm{H}}=0.8 \mathrm{~Hz}, 3 \mathrm{H}\right), 1.41\left(\mathrm{~d},{ }^{3} J_{\mathrm{H}-\mathrm{H}}=0.8 \mathrm{~Hz}, 3 \mathrm{H}\right), 0.91\left(\mathrm{~d},{ }^{3} J_{\mathrm{H}-\mathrm{H}}=6.6 \mathrm{~Hz}, 3 \mathrm{H}\right)$.

11b: ${ }^{1} \mathrm{H}-\mathrm{NMR}\left(400 \mathrm{MHz}, \mathrm{C}_{6} \mathrm{D}_{6}\right): \delta=6.89(\mathrm{~s}, 1 \mathrm{H}), 6.88(\mathrm{~s}, 1 \mathrm{H}), 5.75-5.70(\mathrm{~m}, 1 \mathrm{H}), 4.47-4.46(\mathrm{~m}, 1 \mathrm{H})$, 4.07-4.06 (m, 1H), $2.54(\mathrm{~s}, 3 \mathrm{H}), 2.52(\mathrm{~s}, 3 \mathrm{H}), 2.36(\mathrm{~s}, 3 \mathrm{H}), 2.33(\mathrm{~s}, 3 \mathrm{H}), 2.10(\mathrm{~s}, 3 \mathrm{H}), 2.09(\mathrm{~s}, 9 \mathrm{H}), 2.07(\mathrm{~s}$, $3 \mathrm{H}), 1.98\left(\mathrm{~d},{ }^{3} J_{\mathrm{H}-\mathrm{H}}=1.1 \mathrm{~Hz}, 3 \mathrm{H}\right), 1.45\left(\mathrm{~d},{ }^{3} J_{\mathrm{H}-\mathrm{H}}=1.1 \mathrm{~Hz}, 3 \mathrm{H}\right), 1.13\left(\mathrm{~d},{ }^{3} J_{\mathrm{H}-\mathrm{H}}=8.0 \mathrm{~Hz}, 3 \mathrm{H}\right)$.

11a + 11b: $\left.{ }^{13} \mathrm{C}_{1}{ }^{1} \mathrm{H}\right\}-N M R\left(101 \mathrm{MHz}, \mathrm{C}_{6} \mathrm{D}_{6}\right): \delta=152.0,151.4,133.7,133.6,133.6,133.5,133.4$, 133.3, 133.2, 133.2, 132.6, 132.2, 132.1, 132.0, 131.7, 131.4, 131.4, 131.1, 130.8, 129.9, 105.6, 101.7, 61.2, 
$60.8,22.8,22.6,20.2,20.1,20.0,19.7,19.7,19.6,19.5,19.4,19.3,19.3,19.2,19.2,19.2,19.1,18.9,18.1$, $17.9,15.4$. The carbon atom directly attached to boron was not detected, likely due to quadrupolar broadening. ${ }^{11}$ B-NMR $\left(128 \mathrm{MHz}, \mathrm{C}_{6} \mathrm{D}_{6}\right): \delta=39.1$. HRMS: calc. for $[\mathrm{M}+\mathrm{H}]^{+} \mathrm{C}_{28} \mathrm{H}_{39} \mathrm{~N}_{2} \mathrm{~B}_{2} \mathrm{Br}_{2}{ }^{+}$ 585.16402; found: 585.16454 .

\subsection{Synthesis of $\mathbf{1 3} a$ and $\mathbf{1 3 b}$}

In the glove box, (TMS) ${ }_{2} \mathrm{NBCl}_{2}\left(86.4 \mathrm{mg}, 0.2 \mathrm{mmol}, 2\right.$ equiv.) and 1, $1^{\prime}$-bis(trimethylsilyl)-1H, $1^{\prime} \mathrm{H}$ 4,4'-bipyridinylidene (12) $\left(30.2 \mathrm{mg}, 0.1 \mathrm{mmol}, 1\right.$ equiv.) were added into $\mathrm{C}_{6} \mathrm{D}_{6}(0.6 \mathrm{~mL})$. The mixture was rested for $10 \mathrm{~min}$ prior to the removal of the volatiles under vacuum to get a yellowish green powder. The yellowish green powder was extracted with hexane, filtered, and the solvent was again removed under reduced pressure to yield 13 as a yellow powder $(60.0 \mathrm{mg}, 0.84 \mathrm{mmol}, 84 \%)$. The ratio of $13 \mathbf{a}: 13 \mathbf{b}$ is ca. $1: 1$.

13a + 13b: ${ }^{1} \mathrm{H}-\mathrm{NMR}\left(400 \mathrm{MHz}, \mathrm{C}_{6} \mathrm{D}_{6}\right): \delta=6.87(\mathrm{br}, 8 \mathrm{H}), 5.79\left(\mathrm{~d}^{3} J_{\mathrm{H}-\mathrm{H}}=8.1 \mathrm{~Hz}, 8 \mathrm{H}\right), 0.21(\mathrm{~s}, 72 \mathrm{H})$. $\left.{ }^{13} \mathrm{C}^{1}{ }^{1} \mathrm{H}\right\}$-NMR $\left(101 \mathrm{MHz}, \mathrm{C}_{6} \mathrm{D}_{6}\right): \delta=114.3,111.3,2.25$ (C of TMS). The carbon atom directly attached to boron was not detected, likely due to quadrupolar broadening. ${ }^{11} \mathbf{B}-\mathbf{N M R}\left(128 \mathrm{MHz}, \mathrm{C}_{6} \mathrm{D}_{6}\right): \delta=34.4$. HRMS: calc. for $[\mathrm{M}]^{+} \mathrm{C}_{22} \mathrm{H}_{44} \mathrm{~N}_{4} \mathrm{~B}_{2} \mathrm{Cl}_{2} \mathrm{Si}_{4}{ }^{+}$568.22007; found: 568.21887 .

\section{Conclusions}

In summary, the reactions of electron-rich organosilicon compounds 1, 2, and 12 with various $B$-amino and $B$-aryl dihaloboranes were comprehensively studied. No direct evidence for the presence of divalent boron radical character could be obtained from NMR spectra and single-crystal structures. The rotational barrier around the exocyclic B-N bonds was studied by VT ${ }^{1} \mathrm{H}-\mathrm{NMR}$ spectroscopy, which revealed relatively small barriers for $\mathbf{1 0}$ and $\mathbf{1 3}$. The steric hindrance as well as the competition from additional $B$-amino functions were the main factors affecting the $\mathrm{B}-\mathrm{N}$ rotational barrier. In addition, the reaction between $\mathbf{2}$ and $\mathrm{DurBBr}_{2}$ resulted in $\mathbf{1 1}$ via an isomerization process. Although this study does not access the desired biradial species, we believe that the novel $\mathrm{B}=\mathrm{N}$-containing products could act as an RXB• source upon the liberation of the aromatic linker (i.e., pyrazine and 4, $4^{\prime}$-bipyridine). Studies of the mechanism of the isomerization reaction, as well as the application of $\mathbf{1 0}$ and $\mathbf{1 3}$ as RXB• transfer reagents to unsaturated organic substrates, are currently underway in our laboratory, and will be reported in due course.

Supplementary Materials: Supplementary materials are available online. Figures S1-S31: NMR spectra for 3-11, 13. Figures S32-S36: Variable-temperature ${ }^{1} \mathrm{H}-\mathrm{NMR}$ spectra for 7, 10, and 13. Figures S37-S41, Single crystal structure for 5, 9-11, and 13. Table S1: Crystal data for 5, 9-11, and 13.

Author Contributions: Q.Y. conceived and designed the experiments; L.M., X.Z., S.S., and W.M. performed the experiments; L.M., W.M., and Q.Y. analyzed the data; L.M., X.Z., and X.C. tested and refined single crystals. L.M., W.M., and Q.Y. wrote the paper. All authors have read and agreed to the published version of the manuscript.

Funding: This research was funded by the start-up fund of SUSTech.

Acknowledgments: The authors thank Zhanying Ren, Yinhua Yang, and Jianfei Qu (SUSTech) for the VT NMR measurement, and Hua Li (SUSTech) for the HRMS measurement.

Conflicts of Interest: The authors declare no conflicts of interest.

\section{References}

1. Krasowska, M.; Bettinger, H.F. Reactivity of borylenes toward ethyne, ethene, and methane. J. Am. Chem. Soc. 2012, 134, 17094-17103. [CrossRef] [PubMed]

2. Krasowska, M.; Edelmann, M.; Bettinger, H.F. Electronically excited states of borylenes. J. Phys. Chem. A 2016, 120, 6332-6341. [CrossRef] [PubMed]

3. Wang, Y.; Robinson, G.H. Carbene stabilization of highly reactive main-group molecules. Inorg. Chem. 2011, 50, 12326-12337. [CrossRef] [PubMed] 
4. $\quad$ Bissinger, P.; Braunschweig, H.; Damme, A.; Dewhurst, R.D.; Kupfer, T.; Radacki, K.; Wagner, K. Generation of a carbene-stabilized bora-borylene and its insertion into a $\mathrm{C}-\mathrm{H}$ bond. J. Am. Chem. Soc. 2011, 133, 19044-19047. [CrossRef] [PubMed]

5. Bissinger, P.; Braunschweig, H.; Kraft, K.; Kupfer, T. Trapping the elusive parent borylene. Angew. Chem. Int. Ed. 2011, 50, 4704-4707. [CrossRef] [PubMed]

6. Curran, D.P.; Boussonnière, A.; Geib, S.J.; Lacôte, E. The parent borylene: Betwixt and between. Angew. Chem. Int. Ed. 2012, 51, 1602-1605. [CrossRef]

7. Braunschweig, H.; Claes, C.; Damme, A.; Deißenberger, A.; Dewhurst, R.D.; Hörl, C.; Kramer, T. A facile and selective route to remarkably inert monocyclic NHC-stabilized boriranes. Chem. Commun. 2015, 51, 1627-1630. [CrossRef]

8. Frey, G.D.; Lavallo, V.; Donnadieu, B.; Schoeller, W.W.; Bertrand, G. Facile splitting of hydrogen and ammonia by nucleophilic activation at a single carbon center. Science 2007, 316, 439-441. [CrossRef]

9. Légaré, M.-A.; Bélanger-Chabot, G.; Dewhurst, R.D.; Welz, E.; Krummenacher, I.; Engels, B.; Braunschweig, H. Nitrogen fixation and reduction at boron. Science 2018, 359, 896-900. [CrossRef]

10. Légaré, M.-A.; Rang, M.; Bélanger-Chabot, G.; Schweizer, J.I.; Krummenacher, I.; Bertermann, R.; Arrowsmith, M.; Holthausen, M.C.; Braunschweig, H. The reductive coupling of dinitrogen. Science 2019, 363, 1329-1332. [CrossRef]

11. Krasowska, M.; Bettinger, H.F. Ring enlargement of three-membered boron heterocycles upon reaction with organic $\pi$ systems: Implications for the trapping of borylenes. Chem. Eur. J. 2016, 22, 10661-10670. [CrossRef] [PubMed]

12. Timms, P.L. Boron-fluorine chemistry. I. Boron monofluoride and some derivatives. J. Am. Chem. Soc. 1967, 89, 1629-1632. [CrossRef]

13. Timms, P.L. Chemistry of boron and silicon subhalides. Acc. Chem. Res. 1973, 6, 118-123. [CrossRef]

14. Wang, Y.; Quillian, B.; Wei, P.; Wannere, C.S.; Xie, Y.; King, R.B.; Schaefer, H.F.; Schleyer, P.v.R.; Robinson, G.H. A stable neutral diborene containing a B=B double bond. J. Am. Chem. Soc. 2007, 129, 12412-12413. [CrossRef] [PubMed]

15. Kinjo, R.; Donnadieu, B.; Celik, M.A.; Frenking, G.; Bertrand, G. Synthesis and characterization of a neutral tricoordinate organoboron isoelectronic with amines. Science 2011, 333, 610-613. [CrossRef]

16. Woon, E.C.Y.; Tumber, A.; Kawamura, A.; Hillringhaus, L.; Ge, W.; Rose, N.R.; Ma, J.H.Y.; Chan, M.C.; Walport, L.J.; Che, K.H.; et al. Linking of 2-oxoglutarate and substrate binding sites enables potent and highly selective inhibition of Jmjc histone demethylases. Angew. Chem. Int. Ed. 2012, 51, 1631-1634. [CrossRef]

17. Kong, L.; Li, Y.; Ganguly, R.; Vidovic, D.; Kinjo, R. Isolation of a bis(oxazol-2-ylidene)-phenylborylene adduct and its reactivity as a boron-centered nucleophile. Angew. Chem. Int. Ed. 2014, 53, 9280-9283. [CrossRef]

18. Wang, H.; Zhang, J.; Lin, Z.; Xie, Z. Synthesis and structural characterization of carbene-stabilized carborane-fused azaborolyl radical cation and dicarbollyl-fused azaborole. Organometallics 2016, 35, 2579-2582. [CrossRef]

19. Lu, W.; Li, Y.; Ganguly, R.; Kinjo, R. Alkene-carbene isomerization induced by borane: Access to an asymmetrical diborene. J. Am. Chem. Soc. 2017, 139, 5047-5050. [CrossRef]

20. Wang, H.; Zhang, J.; Lin, Z.; Xie, Z. The synthesis and structure of a carbene-stabilized iminocarboranyl-boron(I) compound. Chem. Commun. 2015, 51, 16817-16820. [CrossRef]

21. Ruiz, D.A.; Melaimi, M.; Bertrand, G. An efficient synthetic route to stable bis(carbene)borylenes $\left[\left(\mathrm{L}_{1}\right)\left(\mathrm{L}_{2}\right) \mathrm{BH}\right]$. Chem. Commun. 2014, 50, 7837-7839. [CrossRef] [PubMed]

22. Hahn, F.E.; Wittenbecher, L.; Boese, R.; Bläser, D. N,N'-bis(2,2-dimethylpropyl)benzimidazolin-2-ylidene: A stable nucleophilic carbene derived from benzimidazole. Chem. Eur. J. 1999, 5, 1931-1935. [CrossRef]

23. Lavallo, V.; Canac, Y.; Donnadieu, B.; Schoeller, W.W.; Bertrand, G. Cyclopropenylidenes: From interstellar space to an isolated derivative in the laboratory. Science 2006, 312, 722-724. [CrossRef]

24. Connelly, N.G.; Geiger, W.E. Chemical redox agents for organometallic chemistry. Chem. Rev. 1996, 96, 877-910. [CrossRef] [PubMed]

25. Broggi, J.; Terme, T.; Vanelle, P. Organic electron donors as powerful single-electron reducing agents in organic synthesis. Angew. Chem. Int. Ed. 2014, 53, 384-413. [CrossRef] [PubMed]

26. Eberle, B.; Hubner, O.; Ziesak, A.; Kaifer, E.; Himmel, H.J. What makes a strong organic electron donor (or acceptor)? Chem. Eur. J. 2015, 21, 8578-8590. [CrossRef] 
27. Tsurugi, H.; Saito, T.; Tanahashi, H.; Arnold, J.; Mashima, K. Carbon radical generation by $\mathrm{d}^{0}$ tantalum complexes with $\alpha$-diimine ligands through ligand-centered redox processes. J. Am. Chem. Soc. 2011, 133, 18673-18683. [CrossRef]

28. Tsurugi, H.; Tanahashi, H.; Nishiyama, H.; Fegler, W.; Saito, T.; Sauer, A.; Okuda, J.; Mashima, K. Salt-free reducing reagent of bis(trimethylsilyl)cyclohexadiene mediates multielectron reduction of chloride complexes of W(VI) and W(IV). J. Am. Chem. Soc. 2013, 135, 5986-5989. [CrossRef]

29. Saito, T.; Nishiyama, H.; Tanahashi, H.; Kawakita, K.; Tsurugi, H.; Mashima, K. 1,4-bis(trimethylsilyl)-1,4-diaza-2,5-cyclohexadienes as strong salt-free reductants for generating low-valent early transition metals with electron-donating ligands. J. Am. Chem. Soc. 2014, 136, 5161-5170. [CrossRef]

30. Tsurugi, H.; Mashima, K. A new protocol to generate catalytically active species of group 4-6 metals by organosilicon-based salt-free reductants. Chem. Eur. J. 2019, 25, 913-919. [CrossRef]

31. Arteaga-Muller, R.; Tsurugi, H.; Saito, T.; Yanagawa, M.; Oda, S.; Mashima, K. New tantalum ligand-free catalyst system for highly selective trimerization of ethylene affording 1-hexene: New evidence of a metallacycle mechanism. J. Am. Chem. Soc. 2009, 131, 5370-5371. [CrossRef] [PubMed]

32. Saito, T.; Nishiyama, H.; Kawakita, K.; Nechayev, M.; Kriegel, B.; Tsurugi, H.; Arnold, J.; Mashima, K. Reduction of ( $\left.{ }^{t} \mathrm{BuN}=\right) \mathrm{NbCl}_{3}(\mathrm{py})_{2}$ in a salt-free manner for generating $\mathrm{Nb}(\mathrm{IV})$ dinuclear complexes and their reactivity toward benzo[c] cinnoline. Inorg. Chem. 2015, 54, 6004-6009. [CrossRef] [PubMed]

33. Tanahashi, H.; Ikeda, H.; Tsurugi, H.; Mashima, K. Synthesis and characterization of paramagnetic tungsten imido complexes bearing $\alpha$-diimine ligands. Inorg. Chem. 2016, 55, 1446-1452. [CrossRef] [PubMed]

34. Weyenberg, D.R.; Toporcer, L.H. The synthesis of 3,6-disilyl-1,4-cyclohexadienes by the trapping of benzene anion-radicals. J. Am. Chem. Soc. 1962, 84, 2843-2844. [CrossRef]

35. Braunschweig, H.; Ye, Q.; Radacki, K. High yield synthesis of a neutral and carbonyl-rich terminal arylborylene complex. Chem. Commun. 2012, 48, 2701-2703. [CrossRef]

36. Cowherd, F.G.; Von Rosenberg, J.L. Mechanism of iron pentacarbonyl-catalyzed 1,3-hydrogen shifts. J. Am. Chem. Soc. 1969, 91, 2157-2158. [CrossRef]

37. Hvistendahl, G.; Williams, D.H. Energy barrier to symmetry-forbidden 1,3-hydrogen shifts in simple oxonium ions. Metastable peaks from fast dissociations. J. Am. Chem. Soc. 1975, 97, 3097-3101. [CrossRef]

38. Laguerre, M.; Dunogues, J.; Calas, R.; Duffaut, N. Silylation d'hydrocarbures mono-aromatiques mono- ou disubstitues. J. Organomet. Chem. 1976, 112, 49-59. [CrossRef]

39. Lis, A.V.; Gostevskii, B.A.; Albanov, A.I.; Yarosh, N.O.; Rakhlin, V.I. Synthesis of volatile bis[bis(trimethylsilyl)amide]-substituted boron derivatives. Russ. J. Gen. Chem. 2017, 87, 353-356. [CrossRef]

40. Brown, C.; Cragg, R.H.; Miller, T.J.; Smith, D.O.N. Organoboron compounds: Xxii. A ${ }^{13}$ C NMR study of some dialkylaminophenylboranes. J. Organomet. Chem. 1983, 244, 209-215. [CrossRef]

Sample Availability: Samples of the compounds are not available from the authors.

(C) 2020 by the authors. Licensee MDPI, Basel, Switzerland. This article is an open access article distributed under the terms and conditions of the Creative Commons Attribution (CC BY) license (http://creativecommons.org/licenses/by/4.0/). 